\title{
Biopolitics, Life, and Body... Considerations from Latin American Point of View
}

\author{
Luciana Alvarez \\ Universidad Nacional de Cuyo
}

\begin{abstract}
We intend to get a close look at Foucault's work on biopolitics with the aim of contrasting some of its aspects with the developments linked to the emancipatory and liberating potential of the notion of life (living corporeality) within the framework of Enrique Dussel's Latin American Political Philosophy. We are interested in these theoretical approaches (Foucault's biopolitics and Dussel's Liberation Politics) given the political implications and prominence they grant to the notions of body and life in contemporary societies. The works we are interested in to contrast present different standpoints: In the first one, life is related to the exercise of political power, whereas in the second one its approach concentrates on political emancipation processes. We believe, however, that it is possible to find convergence points between them that allow us to explain, to a certain extent, the importance of the notion of life in contemporary societies. For this purpose, we will carry out an analysis of the notion of "counter behaviors," a concept that Foucault briefly develops to explain how life has not been thoroughly integrated to technologies that dominate or run it but instead escape them ceaselessly.
\end{abstract}

Keywords: biopolitics, body, life, Latin American philosophy

\section{Introduction}

The philosophical categories of body and life, in the sense that they have been developed by some Latin American philosophers, that is to say near to the philosophical category of conflict, allow us to think the political beyond management and institutional organization. In the same way, this approach contributes to go deeper into a perspective in which it is possible to conceive the juridical and the political as part of a dynamics of social transformation where life is always at stake. This is why we intend to get a close look at Foucault's work on biopolitics, focusing the notion of counter-conduct with the aim of contrasting some of its aspects with the developments linked to the emancipatory and liberating potential of the notion of life (living corporeality) within the framework of Enrique Dussel's Latin American Political Philosophy. This exercise also pretends to elucidate emancipatory posibilities within contemporary juridical practices. For this purpose, we will carry out an analysis of the notion of "counter-conducts," a concept that Foucault briefly developed to explain how life has not been thoroughly integrated to technologies (economical, juridical, political, cultural, or medical) that dominate it or run it but instead escapes them ceaselessly. After that we are going to develop some Dussel's ideas around notion of life, body, and emancipation in order to make visible certain converging points between

Luciana Alvarez, lawyer, Ph.D. in Law, researcher at CONICET (National Council of Scientific and Technological Research), Sociology and Philosophy of Law Department, Universidad Nacional de Cuyo, Argentina; main research field: Philosophy of Law and Political Philosophy. Email: lula276@yahoo.com. 
Dussel and Foucault.

\section{Biopolitics and Counter-conduct}

Foucault's work corresponding to the 1976-1979 lectures at the Collège de France Foucault (2000, 2006, 2007) intends to develop an analysis of political power, not as what substitutes law nor what law allows in terms of sovereignty, but as relationship between powers. Notwithstanding the fact that he has already given a brief reference in The history of sexuality I (1977), he starts to analyze the legal, institutional, technological, scientific, police, and economic mechanisms by that life and the human species play a role within the political power's own strategies. This biopolitics seems to become clearer from the second half of the 18th century and enables us to differentiate two kinds of rationality which seem to have the aim of imposing limits to power: One, originated during the 16th and 17th centuries and focused on the law as an external limit to political power; the other, typical of biopolitics, focused on the administration of the population's life, where limits work internally by scientific rationality, specially the economic one.

In very general terms, Foucault holds that modernity would have emerged a way of controlling the political power by which this power is adjusted to a new rationality $(2007,356-7)$. During the 16th and 17th centuries, the State rationality understood as sovereign individuality ${ }^{1}$ pointed out that it was necessary to “... arrange things so that the state becomes sturdy and permanent, so that it becomes wealthy, and so that it becomes strong in the face of everything that may destroy it..." (Foucault 2006, 19). That is to say, the interest of political power is focused in the state and its allowance. Given this state will, the only possible limit is enabled in terms of sovereignty rights. Thus, law is an external limit to the government and therefore capable to object its activities in case they go beyond the legitimate exercise scope of its power.

Later, in mid-18th century, a new form of rationality ${ }^{2}$ seems to have emerged from within the political power exercise itself. It is consisting in an internal control of the art of government under which the state would respect, as a fundamental principle, the natural processes which are inherent to economy and population. In other words, it would be necessary for the state to keep natural phenomena within a framework in such a way, by which they do not deviate by a clumsy, arbitrary, or blind intervention. Therefore, it is no longer about law as an external limit but instead about the need to know natural regularities scientifically. In this way, the political power would find itself internally structured and limited by the regularities governing the phenomena it administers: population, natural resources, and economic flows. Foucault called this new form of political rationality "biopolitics" or "biopower," given that it involves the inclusion of natural life into the mechanisms and calculations of state power. Accordingly, instead of the juridico-institutional aspects of political power, the analysis of political power would concentrate on the concrete ways in which power penetrates in the actual body of the subjects and their lives (Agamben 1998, 14).

From this transformation, we can also observe a shift from legitimacy to usefulness; in such way, the state would not take care of what it can or cannot legally do, ${ }^{3}$ but instead what is useful doing for the governed people. In a way, it is not a problem of not thinking in terms of legitimacy anymore, but instead legitimacy is no longer thought to be given by the sovereign power of law but rather by usefulness. Thus, any government would be considered legitimate as long as the development of its activities takes into consideration the laws set by the manipulated objects' own nature, that is phenomena, processes, and regularities applicable to population, climate, territory, and economic flows (Foucault 2007, 32-33).

This shifting process refers especially to politics as a specific and historical form of exercising power on 
the basis of a determined arrangement of the social relations. ${ }^{4}$ Still, the concept of biopolitics does not deny the consideration of its resistances, and it could not do it according to the Foucauldian conception of power. This is because the administration of life "... does not mean life has been exhaustively integrated to techniques that dominate it or administer it; it escapes them ceaselessly..." $(2007,173)$ Foucault dedicated both March first and eighth lectures in 1978 (2006, 221-91), to what he denominated "counter-conducts" with regards to the social resistances displayed at facing Middle Age pastorate. In these lectures, he mentions the existence of a structural correlation between: On the one hand, rules and proceedings aiming at leading the behavior of the governed; on the other, the actions displayed by those who do not accept to be led in certain ways or by certain people $(2007,222-7)$.

The exercise of power and political power specifically, can only be comprehended once it is approached within the framework of a determined power relationship. At the beginning of his Homo Sacer, Agamben points out the presence of two distinct directives in Foucault's research that correspond to this period: one related to the political techniques with which the State assumes the control of life (that is biopolitics); the other related to the mechanisms by which processes of subjectivization bring the individual to bind himself to his own identity and conciousness and, at the same time, to an external power (that is technologies of the self) $(1998,14)$.

Nevertheless, according to the developments around the counter-conducts displayed by different groups and individuals when facing the leading and obedience techniques of the pastorate, it appears certainly clear at least for Foucault that the techniques or mechanisms, by which a determined obedience or behaviour is thought to be guaranteed, are not in any way infallible. The form in which these counter-conducts are displayed as behaviours that escape the governing ability of the pastor (and later on any governing authority ${ }^{5}$ ) maintains a non autonomous specificity given that all of them are linked to the main problem that goes through power exercise: the behaviour. It is indeed by means of the behaviour that one can observe and comprehend a certain course of action as resistance (Foucault 2006, 232). In the same direction, Agamben mentions the possibility of displaying "counter-devices" as a way to resist the subjectivization of the devices as government agency (Agamben 2007, 40).

In other words, if the problem of power in its biopolitical determination is related to the government or the conduction of the governed, what escapes from all of this constitutes a resistance to being conducted by determined people or determined principles of action. ${ }^{6}$ At the same time, as resistance, a subject's practice aimed at conducting his self by himself has a productive nature given that it involves leading himself according to his own choices which are beyond any government technology. ${ }^{7}$ In regards to this, Foucault holds it expressly: “... we may have to suspect that we find it impossible today to constitute an ethic of the self even though it may be an urgent, fundamental, and politically indispensable task; if it is true after all that, there is no first or final point of resistance to political power other than in the relationship that one has to oneself' (2009, 246).

The consideration of contemporary forms of political power exercise and their relationship to the control of population's life makes up a problem that following to certain points, Foucalt's reasonings have been resumed by european contemporary authors. ${ }^{8}$ One of them, Agamben, suggests to characterize the contemporary form of political power exercise not any longer as linked to the inclusion of population ${ }^{9}$ within the calculations and strategies of state agencies but rather understanding that state and private grounds, the included and excluded, and the rules and exceptions have all become indistinguishable. It is this lack of distinction that what doesn't allow at present the return of zoé to the sphere of the subject. This is why at the 
end of his Homo Sacer he holds that not even the idea of "another" economy of bodies and pleasures seems to offer us solid grounds against the sovereign power's will, since even the concepts of body, sex, or sexuality are always trapped in some device (1998, 237-8).

\section{Life as Living Corporality and Emancipation in Dussel's Perspective}

Enrique Dussel suggests an Ethics from a politics of liberation in 2001 where it is possible to conceive a universal content: human life. According to Dussel, human life constitutes a universal material principle for ethics and politics, as human beings are living corporeality and their reality mode is life. Unlike dualisms such as body/spirit or body/mind, Dussel believes that corporeality makes the human beings reality mode. The body seems not to be given to the spirit as a passive object, but instead we are corporeal and we are living corporeality (Dussel 2001, 71-2). ${ }^{10}$ Dussel does not distinguish mere corporeal life as animal life from spiritual life, but instead he places human existence within the living corporeality. In the same way, we can suggest that zoé (the vital as what is shared with the rest of the organism) cannot be separated from bios (as spiritual, cultural, and rational life). While life conservation is an existential mandate in the reality mode of human beings, this mandate does not constitute a record at an animal level, but at a human one. That is to say, as human beings, we are corporeal beings who conserve our lives.

Human life as a truth criterion refers to the ethical political obligation to create, reproduce, and develop the concrete human life of each community subject at physical-biological, cultural-historical, ethical-aesthetic, and mythical-spiritual levels. Given the fact that our mind, through non-conscious brain activity, considers the need to carry out certain acts which are usually thought to be only instinctive, for the conservation of one's own life for instance, such as drinking water when we are thirsty, we are faced with practical judgments developed on the basis of human life conservation criterion which enables us to consider them true $(2001,116)$. In this way, every act which would contribute to conservation, production, and reproduction of human life in all the aforementioned aspects would be valid, ethically, and politically.

By means of this human life production and reproduction imperative, the denial which is evident in the suffering corporeality of the victims indicates, especially to the victims themselves, the need to deny such denial of life. Thus, life support and protection are therefore produced as denial of the denied life, involving at the same time the transformation of the system/totality. Dussel makes a distinction between totality system and exteriority: The current system is constituted by totality, as a world of sense and the "same" which is identical to itself. ${ }^{11}$ Inside the totality, we can find a slight difference between the same and the other, but opposite to totality, there is the exteriority/the other which constitutes an experience that exceeds it radically. The idea of the other radicality enables Dussel to approach the problem of the necessary transformation of the system starting from the emergence of alien elements to it, since if these elements were just a part of the other within totality, we would be facing an internal movement of the system which would prove incapable of transforming it. As long as it enables the production and the development of the other's life from the other's perspective (not from the totality's), the new system constitutes a liberating step in the neverending way towards the liberation of the oppressed. Therefore, Dussel does not speak of "inclusion" of the other, while he holds explicitly: “... the excluded must not be included in the old system (since that would be like including the other in the same), but instead they must participate as equals in a new institutional momentum... We are not fighting for inclusion but for transformation..." $(2006,106)$.

In this sense, we can observe Dussel's proposal depending on legitimacy thought in different terms. 
Legitimacy would be given not only by the material content, that is human life as an evaluation criterion, but instead by the way in which such life demand entails a social transformation. We can speak of transformation since there is an exteriority which is foreign to the system and its devices, and subjecting technologies, and an exteriority that questions and bursts into its institutional structures, claiming for its life. At a first stage, Dussel mentions democratic legitimacy as the participation of all the affected in the deliberation process for decision making in a community. However, it is this purely procedural aspect that which is criticized by Dussel as corresponding to the juridico-institutional model of power analysis for following the architecture of discourse ethics suggested by Apel or Habermas. ${ }^{12}$ Unlike them, he holds that the ethics-politics of liberation is material because it is only through human life assertion; as denial of denied life, that subjects start to share the "dialogue." So there is no emancipating dialogue without the conservation, production, and reproduction of the other's human life from the other's reality.

From a Dusselian perspective, the irruption of the world of the other entails the irruption into the totality system of the vital and corporeal world of the other who inhabits the exteriority. Thus, the denial of human life coincides with the support of the other's life, biography, culture, and history, and in this sense, denial becomes creative disruption. Despite the fact that Dussel had firstly placed more emphasis on the support of the other and exteriority as a positive entity, he later accepted that there is a step forward that positivity and he held that "a stronger presence of the negative and material are observed." This would also establish the emergence of the victim category rather than the other category. This is because the latter refers mainly to the positive aspects of subjectivity content whilst the former highlights the relational aspects of the subjectivity constitution, that is to say, the negative dialectic aspects regard the relations between totality/exteriority and system/excluded individuals.

The creative disruption would constitute a speech act through which the other and the victims appear in the communication community, the current institutionality, and the totality, and claim for their life. Taking the irruption of the other, the victim, and the ones resisting as a non-agreement and dissent, enables us to relate this to the way where Foucault posed the question of counter-conduct. These counter-conducts could only be understood by considering the double aspect behind the conduct notion: On the one hand, a counter-conduct objects a determined conduction; but on the other hand, it involves the support of a self-conduction. This means the counter-conduct translates its negative and positive faces. A counter-conduct would not be obtained only by disobeying ${ }^{13}$ the direction or order imposed by the pastor, governor, and the system as a totality, but by facing through a determined conduction, ${ }^{14}$ which is the procedure and/or device carried out in order to conduct others. Something, following Dussel's terms, could be understood if considering the irruption of the others who get to transform, within the system what prevents them from creating and reproducing their life from themselves. In other words, they legitimize, within the system and the victims' biological, cultural, historical, and spiritual lives, who from this irruption act create their self from themselves.

Dussel's liberation practice appears as assertion of what doesn't have place, and these no places within the dominating totality are the "not-being," that, however are real (Dussel 1993, 18). Here we encounter a key perspective for Dussel that Agamben's developments would not admit easily: That is the existence of a exteriority of the other whose body constitutes something more than a suffering corporeality and something somehow free from devices and from where it is possible to found a different politics. On a short footnote, the editors of Security, territory, and population highlight the following phrase written by Foucault in the manuscripts of his lectures in 1978 where he worked the notion of counter-conducts as political practices of the 
resistance: "... Politics is no more or less than that which is born with resistance to governmentality..."15

\section{Conclusion}

According to Latin American philosophy ideas which we have already referred to, it is possible to notice some ways of escaping from political power in the framework of a biopolitical rationality, which is concerned about increasing life as a way of increasing the domination power. In this sense, the notion of life, as the living corporeality developed by Dussel, could be perceived as a contribution to political power exercise, but on the other hand, the Foucauldian notion of counter-conduct suggests an alternative direction: Resistance is about putting on practice life manners aliened to not only contemporary political power exercise, in which people could develop strategies that allow them to bear another relation to themselves beyond political power needs. At this point, we believe that Latin American philosophy perspective could contribute to: The irruption of the other (the affirmation of his own life) always implies a crisis within the totality order (governmentality), since the world of the other involves something immeasurable that unavoidably transforms it.

\section{Notes}

1. It is important to bear in mind how, at this point in history, State sovereignty was highly linked to the body of the king, in such a manner that both the state's sovereign power and the king's sovereign power appeared to be almost indistinguishable as an effect of what has been known as the "King's two bodies" (Kantorowicz 1957). This is why Foucault will hold that in the 18th and 19th centuries, there was a certain democratization of sovereignty structured as a critical instrument against monarchy by which individual rights were constituted. It is based on this that thinking in terms of individual rights always brings us to the political power juridical-institutional model (Foucault 2000, 44).

2. According to Foucault these, forms of governmental rationality do not follow each other in succession but intermingle, refute, and fight between them (Foucault 2007, 358).

3. This is in the sense that according to the reason of state of 16th and 17 th centuries, governments can only do what they are legitimized to do. If they go beyond that limit they become illegitimate, unfair, and arbitrary.

4. " ... a current political order is the total amount of institutions and strategic actions carried out within a territory, at a given moment, by a political community...” (Dussel 2007, 307).

5. "... however, from the end of the seventeenth and the beginning of the eighteenths century, generally speaking I think that inasmuch as many pastoral functions were taken up in the exercise of governmentality, and government also begins to want to take responsibility for people's conduct to conduct people, then from then on we see revolts of conduct arising less from the religious institutions and much more from political institutions..." (Foucault 2006, 233). Already in "Truth and juridical forms," Foucault analyses this continuity between the forms of political exercise carried out by religious institutions, specifically the Catholic Church, and the political power exercised by state institutions when studying the emergence of inquiry as a form of power-knowledge. (Foucault 1986, 80-81).

6. Concerning this, Foucault would start distinguishing between moral and ethics, since moral constitutes the observance of rules of behavior imposed by different technologies of power that subjects internalize and conduct their lives accordingly. Ethics, on the contrary, constitutes the mastery of the practices of the subject according to his self, independently of the power mechanisms willing to govern his conduct.

7. Concerning this, Foucault holds that in order to struggle against the disciplinary power which is one of the forms of biopolitics, we should channel towards a new anti-disciplinary lawt, freed from the formal and bourgeois principle of sovereignty. Agamben stated, at the lectures led at the University Paris 8 in 2011, the way Franciscans seem to have resorted to the "use" as a way of life outside law frames, especially property one.

8. We refer particularly to Italian Giorgio Agamben, Roberto Esposito, and Antonio Negri.

9. Specifically, Agamben refers to the incorporation of zoé to the public space, paying special attention to the distinction he made between zoé and bios $(1998,9)$.

10. Dussel, Enrique. Hacia una filosofía política crítica. Bilbao: Desclée de Brouwer, 2001, p. 71-72.

11. "... the world is not a mere sum of beings, but of beings which have a sense for human beings..." (Dussel 1996, 36).

12. For a development on Dussel's critical view on Habermas' and Apel's ethics, you can check Dussel, E.. Hacia una filosofía política crítica, 2001, p. 91-166 \& La ética de la liberación ante el desafío de Apel, Taylor y Vattimo, 1998.

13. Foucault is reluctant to refer to the forms of resistance to the power of conduction of the pastorate under the notion of disobedience since this term is somehow weak and uncapable of showing the productive nature behind these movements given its 
purely negative reference (Foucault 2006, 236).

14. '... I will propose to you the doubtless badly constructed word 'counter-conduct' the latter having the sole advantage of allowing reference to the active sense of the word 'conduct'..." (Foucault 2006, 238).

15. The editor holds right after that "... the idea of "counter-conduct"... represents for Foucault's essential moment lying between the analysis of the subjecting techniques and the one made from 1980 onwards about subjectivation practices..." (Foucault 2006, 225).

\section{Works Cited}

Agamben, Giorgio. What's an Apparatus? And Others Essays. Stanford: Stanford University Press, 2009.

Agamben, Giorgio. Homo Sacer. Sovereign Power and Bare Life. Stanford: Stanford University Press, 1998.

Dussel, Enrique. Materials to a Politics of Liberation. Mexico: Plaza y Valdez Editores, 2007.

Dussel, Enrique. Politics of Liberation. World History and Criticism. Madrid: Trotta, 2007.

Dussel, Enrique. Twenty Theses on Politics. Duke University Press: Durham, 2008.

Dussel, Enrique. Ethics of Liberation in the Age of Globalization and Exclusion. Madrid: Trotta, 2006 (1st ed. 1998).

Dussel, Enrique. Toward a Critical Political Philosophy. Bilbao: Desclée de Brouwer, 2001.

Dussel, Enrique. Ethics of Liberation to the Challenge of Apel, Taylor, Vattimo. México: Universidad Autónoma del Estado México, 1998.

Dussel, Enrique. Philosophy of Liberation. Bogotá: Nueva América, 1996.

Dussel, Enrique. The Underside of Modernity: Apel, Ricoeur, Rorty, Taylor and the Philosophy of Liberation. Humanities Press: NY, 1996.

Foucault, Michel. The Hermeneutics of the Subject: Lectures at the Collège de France 1981-1982. NY: Macmillan, 2005.

Foucault, Michel. The Birth Of Biopolitics: Lectures At The Collège De France, 1978-1979. NY: Picador, 2010.

Foucault, Michel. Security, Territory, Population: Lectures at the College de France 1977-1978. NY: Macmillan, 2009.

Foucault, Michel. Society Must Be Defended: Lectures at the Collège de France, 1975-1976. NY: Macmillan, 2003.

Foucault, Michel. "Truth and Juridical Forms in Power." Essential Works of Foucault, Vol. 3. NY: New Press, 2000.

Foucault, Michel. The History of Sexuality, Vol. 1, An Introduction. NY: Pantheon, 1978.

Kantorowicz, Ernst. The King's Two Bodies. A Study in Medieval Political Theology. New Jersey: Princenton University Press, 1957.

Marchart, Oliver. Post-foundational Political Thought: Political Difference in Nancy, Lefort, Badiou and Laclau. Edinburgh: Edinburgh University Press, 2007.

Rancière, Jacques. Disagreement: Politics and Philosophy. Minnesota: University of Minnesota, 1998. 